\title{
1.1 Теоретико-методологічні основи індивідуалізації навчання в початковій школі
}

Одною 3 актуальних загроз на сучасному етапі розвитку масових технологій навчання $є$ загострення небезпеки втрати унікальності кожної людини, ï здатності обирати власну життєву траєкторію. Шкільна освіта має сприяти формуванню в учнів цілісної уяви про земну цивілізацію, закладати основи розуміння сучасних проблем, в той же час стверджувати ідею ціннісності і унікальності людської особистості.

Індивідуалізація навчання як психолого-педагогічна проблема: історичний ракурс. Вивчення та аналіз першоджерел через призму технологізації та індивідуалізації свідчить про давній інтерес до особистості учня, розвитку його індивідуальності. Проаналізовані технології «Виховання джентльмена» Д. Локка, «Вільного виховання» Ж-Ж. Руссо, «Школа радості» В. О. Сухомлинського та інші дали можливість зрозуміти, що такі підходи завжди існували у будь-якому суспільстві (i як пріоритетні, i як альтернативні). Вивчення історії педагогіки, а саме - навчально-виховних систем, заснованих на основах індивідуалізації навчання, просвітницькій діяльності, життєвих етапах видатних педагогів минулого дало можливість визначити базові принципи індивідуалізованого навчання. Навчання до появи в XVII столітті класноурочної системи носило в тій чи іншій мірі індивідуальний характер, тому проблема індивідуалізації навчання практично не піднімалася. Діти отримували освіту в колі сім'ї або в навчальних закладах, які були створені для людей 3 різним (в основному з достатнім) матеріальним рівнем. В таких закладах не було фіксованого віку дитини для початку навчання, тому існувала можливість переходу з однієї ступені навчання на іншу в індивідуальному темпі в залежності від здібностей, нахилів і матеріальних можливостей. Здобутки з індивідуалізації навчання і виховання в доробку педагогів минулого представлено в таблиці 1. 
Таблиця 1

Педагогічні системи індивідуалізованого навчання в доробку педагогів минулого

\begin{tabular}{|c|c|}
\hline Педагог & Педагогічна система та основні праці \\
\hline $\begin{array}{l}\text { Я. - А. } \\
\text { Коменський }\end{array}$ & $\begin{array}{l}\text { розробив чітку систему навчання і виховання; розкрив сутність основних їі } \\
\text { принципів (наочності, свідомості, активності, послідовності, систематичності } \\
\text { знань, міцного оволодіння знаннями і навичками); вивчив досвід навчання } 3 \\
\text { урочної системи; зробив теоретичне обгрунтування класно-урочної системи } \\
\text { шкільного навчання і сформулював її основоположні принципи; відзначав, що в } \\
\text { центр навчання потрібно поставити дитину зії інтересами, здібностями, життєвим } \\
\text { досвідом, потребами, активністю. Вікова періодизація: чотири вікових періоди по } \\
6 \text { років в кожному. Для кожного періоду було запропоновано свою систему } \\
\text { (школу): дитинство: (від народження до } 6 \text { років) - материнська школа; отроцтво } \\
\text { (6-12 років) - школа рідної мови; юність (12-18 років) - латинська школа чи } \\
\text { гімназія; змужнілість (18-24 років) - академія чи університет. Другим ступенем є } \\
\text { школа рідної мови, навчання в якій повинно проводитись рідною мовою, а } \\
\text { учитися повинні всі діти обох статей, незалежно від станів, віросповідань і } \\
\text { національності. Основна праця: «Велика дидактика». }\end{array}$ \\
\hline А.-В. Ді & 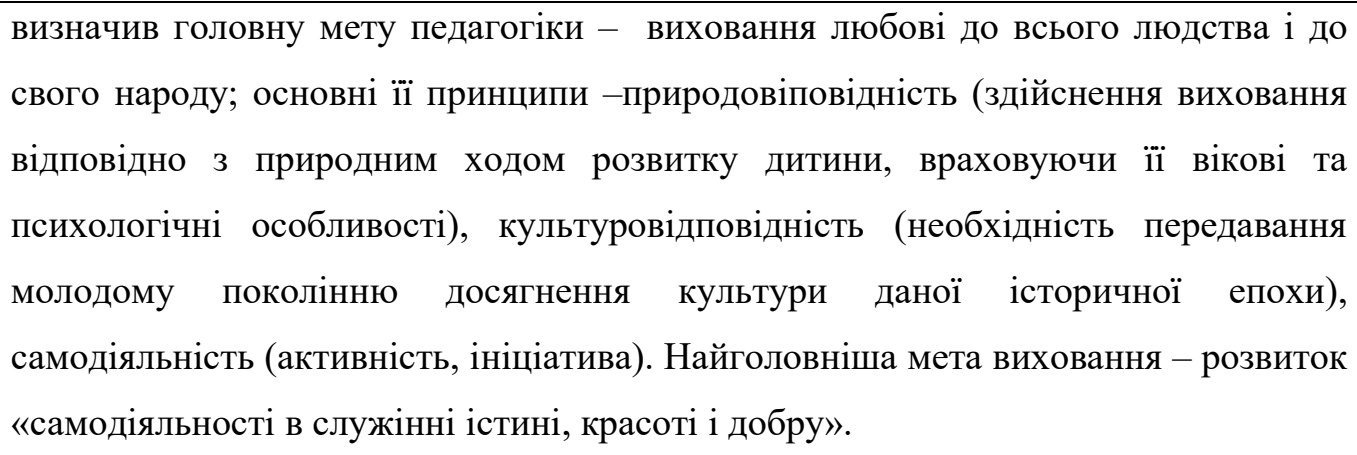 \\
\hline $\begin{array}{l}\text { Й. Г. } \\
\text { Песталоцці }\end{array}$ & $\begin{array}{l}\text { узагальнив власний педагогічний досвід у творах: головна увага на особистості } \\
\text { вихованця як центральної точки всіх виховних дій. Головні положення: моральні, } \\
\text { розумові та фізичні сили людської природи (сили серця, розуму і руки) мають } \\
\text { властивість до діяльності і саморозвитку; основним у вихованні дитини є принцип } \\
\text { природовідповідності (тобто починати з найпростішого і поступово підніматися } \\
\text { до складнішого); роль наочності у розвитку логічного мислення дитини під час } \\
\text { навчання, психологічне обгрунтування. Виходячи із загальнодидактичних } \\
\text { положень, обгрунтував ази методики початкового навчання. Основною вимогою } \\
\text { методики було ведення дитиною спостережень і розвиток власних здібностей. } \\
\text { Вважав необхідним розбуджування та скріплювання духовних сил дитини, ії } \\
\text { морального і суспільного ушляхетнювання. Основні твори: «Лінгард і Гертруда» } \\
\text { (1781-1787), «Як Гертруда вчить своїх дітей» (1801), «Лебедина пісня» (1826). }\end{array}$ \\
\hline
\end{tabular}


THEORETICAL FOUNDATIONS OF THE FUNCTIONING OF EDUCATION. WAYS TO

IMPROVE THE EFFECTIVENESS OF EDUCATIONAL ACTIVITIES

\begin{tabular}{|c|c|}
\hline $\begin{array}{l}\text { К.Д. } \\
\text { Ушинський }\end{array}$ & $\begin{array}{l}\text { основні позиції: для правильної організації навчального процесу треба } \\
\text { систематизувати основні положення і принципи дидактики, грунтовно вивчити та } \\
\text { узагальнити індивідуальні та психологічні особливості розвитку дітей різних } \\
\text { вікових категорій, які випливають із закономірностей процесу пізнання. Вважав, } \\
\text { що педагогіка може стати наукою та мистецтвом, якщо буде тісно пов'язана } 3 \\
\text { життям, виражати потреби суспільства і спиратися на дані наук про людину. } \\
\text { Знаковими є його слова, що коли педагогіка хоче виховувати людину у всіх } \\
\text { відношеннях, то вона повинна взнати його тежу всіх відношеннях. Основні праці: } \\
\text { підручники для початкового навчання «Дитячий світ» (1861), «Рідне слово» } \\
\text { (1864), статті «Три елементи школи» (1867), «Недільні школи» (1861), «Про } \\
\text { початкове викладання російської мови» (1864). }\end{array}$ \\
\hline $\begin{array}{l}\text { Рудольф } \\
\text { Штайнер } \\
\text { (австрійський } \\
\text { філософ } \\
\text { педагог) }\end{array}$ & $\begin{array}{l}\text { сформулював теоретичні і практичні основи вальдорфської педагогіки. Перша } \\
\text { вальдорфська школа була заснована ним у } 1919 \text { році для дітей робітників фабрики } \\
\text { «Вальдорф-Асторія» в г. Штутгарті (Німеччина). Р. Штайнером розроблено } \\
\text { філософське вчення - антропософія, згідно } 3 \text { яким сформульовано основне } \\
\text { завдання педагогіки - привести дитину до пізнання світу, розвинути їі приховані } \\
\text { здібності і можливості; в основу концепції закладено ідею поступального і } \\
\text { цілісного розвитку дитини. Вікова періодизація: дитинство умовно ділиться на } \\
\text { три семирічні стадії, кожна з яких вимагає особливого підходу від педагога: } 1 \\
\text { стадія (0-7 років) - розвиток дитини через співпереживання, імітацію } \\
\text { навколишнього світу (світ добрий); } 2 \text { стадія (7-14 років) - навчання через } \\
\text { пояснення і заняття мистецтвами, які розвивають сферу почуттів (світ } \\
\text { прекрасний); } 3 \text { стадія (14-21 рік)-пізнання світу через власні судження і критичне } \\
\text { мислення (світ правдивий). Тому метою вальдорфських навчальних закладів є не } \\
\text { накопичення знань дитиною, а виховання людини, орієнтованого на навколишній } \\
\text { світ, чутливого до нового, здатного здійснювати усвідомлений вибір і брати на } \\
\text { себе відповідальність за нього. }\end{array}$ \\
\hline M. Mo & $\begin{array}{l}\text { три провідних положення характеризують сутність педагогічної теорії 1) } \\
\text { виховання повинно бути вільним; 2) виховання повинно бути індивідуальним; 3) } \\
\text { виховання повинно спиратися на дані спостережень за дитиною. Реалізувала ідеї } \\
\text { раннього розвитку і вільного виховання, виділила провідну роль духовного } \\
\text { моменту: педагог повинен уміти звертатися до людини, яка дрімає в душі дитини. } \\
\text { Матеріали, що впливають на почуття, спонтанна активність, нові цікаві іграшки, } \\
\text { а також можливість і свобода вчитися за індивідуальною програмою становить } \\
\text { основу методу Монтессорі. }\end{array}$ \\
\hline
\end{tabular}


THEORETICAL FOUNDATIONS OF THE FUNCTIONING OF EDUCATION. WAYS TO

IMPROVE THE EFFECTIVENESS OF EDUCATIONAL ACTIVITIES

\begin{tabular}{|l|l|} 
Василь & Педагогічна система являла собою концептуальну основу особистісно \\
зорієнтованого підходу, що знаходить відображення в компетентнісно \\
орієнтованій освіті. Ця авторська школа являла собою школу радості, спрямовану \\
на виховання всебічно розвиненої особистості, школу співдружності поколінь. \\
Головними суб'єктами цієї системи є учитель, учень та родина, метою - \\
формування всебічно розвиненої особистості, складовими всебічно розвиненої \\
особистості - розумове, моральне, громадянське, трудове, фізичне, естетичне, \\
патріотичне, ідейно-політичне виховання. Гуманістичними основами системи \\
Василя Сухомлинського є: створення для дитини «радості буття»; формування \\
культури бажань, культури почуттів; формування почуття власної гідності; \\
створення атмосфери успіху; перевага позитивних стимулів і реакцій на поведінку \\
дитини над негативними; взаємодія школи, сім'ї, громадськості тощо.
\end{tabular}

Доробок педагогів-гуманістів поступово вплинув на зміни підходів до навчання та виховання дітей i педагогічна наука підтвердила важливість гуманістичного підходу, де основним тезисом є те, що людина - головна цінність, мета і результат організації навчально-виховного процесу.

\section{Індивідуалізація навчання як психолого-педагогічна проблема:}

\section{сучасні підходи.}

Детальніше з провідних позицій гуманітаризації освіти можна виокремити такі: орієнтацію видів діяльності та типу спілкування учнів на гуманістичні ідеали; створення умов для розвитку учнів, актуалізації їхнього потенціалу, стимулювання до особистісного зростання; постійне насичення і збагачення освітнього середовища соціокультурним контекстом, інноваційний розвиток; гуманітаризацію змісту освіти та підручників; розвиток гуманітарної культури і гуманітарного мислення учнів. Усі напрямки гуманізації та гуманітаризації навчання містили в собі цю складову - індивідуальний розвиток дитини, плекання іï особистості. У сучасній педагогічній науці гуманістична освітня парадигма передбачає повну і завершену підготовку здобувача освіти до життя здебільшого через розвиток його індивідуальності та формування особистості (Барановська О., Бех I., Бондар С., Зязюн I., Кизенко В., Корсакова О., Липова Л., Момот Л., Ничкало Н., Паламарчук В., Рибалка В. Савченко О., Трубачева С., Шелестова Л. та ін.). Гуманістична парадигма навчання і виховання особистості перш за все містить індивідуальний підхід до неї, розглядає індивідуалізацію 
THEORETICAL FOUNDATIONS OF THE FUNCTIONING OF EDUCATION. WAYS TO IMPROVE THE EFFECTIVENESS OF EDUCATIONAL ACTIVITIES

навчання як обов’язкову складову процесу навчання. Н. Дічек розглянула внесок вітчизняної експериментальної педагогіки в обгрунтування необхідності індивідуалізації та диференціації навчально-виховного процесу з кінця ХІХ до 1917 року; узагальнила доробок українських психологів у розвиток індивідуалізації навчання школярів (з 40-х по 80-ті роки ХХ століття) [1]. Аналіз розвитку педагогіки в аспекті дитиноцентризму, поглибленні принципу індивідуалізації навчання, засвідчив поступове збільшення таких досліджень на відрізку від 40 до 80-х років і значне збільшення наукових досліджень в 90-2000 роки XX ст. Не зважаючи на деякі відмінності в трактовках, можливості індивідуалізації навчального процесу розглядалися радянськими авторами переважно в рамках колективних форм класно-урочної системи через різноманітні форми та методи навчання. В існуючих на пострадянському просторі педагогічних енциклопедіях та словниках визначення поняття «індивідуалізація навчання» базувалося на врахуванні індивідуальних особливостей дитини i створенні потенційних можливостей в навчальновиховному процесі для їх реалізації; поняття «індивідуальний підхід» визначалося як принцип педагогіки, за якого в навчально-виховній роботі в класі досягається педагогічна взаємодія 3 кожною дитиною, яке базується на знанні його рис особистості та умов життя, розуміння неповторної індивідуальності дитини.

В сучасній психології важливе місце займають концепції соціалізації та індивідуалізації, різноманітні трактовки поняття «індивідуалізація психічного розвитку», яке лежить в основі будь-якого визначення «індивідуалізація навчання». Відзначимо, що поняття індивідуалізації та диференціації навчання розкриваються у багатьох педагогічних дослідженнях, а також дослідженнях на стику педагогіки та психології: А. Кірсанов, І. Осмоловська, В. Паламарчук, Є. Рабунский, Ф. Рафікова, О. Савченко, М. Скаткін, І. Смирнова, І. Унт та ін. Розглянемо дослідження поняття «індивідуалізація» в психологічних та педагогічних дослідженнях радянських та сучасних науковців в аспекті досліджуваної проблеми (таблиця 2). 
Поняття «індивідуалізація» в дослідженнях радянських психологів

\begin{tabular}{|l|l|}
\hline Науковці & Основні напрямки дослідження \\
\hline Л. Виготський & $\begin{array}{l}\text { обгрунтував важливу закономірність розвивальна мета індивідуального } \\
\text { розвитку учнів - це формування і розвиток іхніх інтелектуальних, творчих } \\
\text { здібностей, які мають спиратися на зону найближчого розвитку учня, яка в } \\
\text { подальшому реалізується в реальному часі. }\end{array}$ \\
\hline Д. Ельконін [3] & $\begin{array}{l}\text { вважав, що навчальна діяльність єпровідною в шкільному віці тому, що через неї } \\
\text { здійснюються основні відносини дитини з суспільством; здійснюється } \\
\text { формування основних якостей особистості дитини шкільного віку, окремих } \\
\text { психічних процесів; виникають основні новоутворення, які неможливо зрозуміти } \\
\text { поза аналізом процесу формування навчальної діяльності та ііі рівня. }\end{array}$ \\
\hline В. Давидов [4] & $\begin{array}{l}\text { акцентував на тому, що навчальна діяльність молодших школярів формується } \\
\text { саме в цьому віці, всередині неї виникають відповідні психологічні } \\
\text { новоутворення, вона визначає в даному віці характер інших видів діяльності } \\
\text { (суспільно-організаційної, художньої, спортивної, навчальної, трудової). }\end{array}$ \\
\hline $\begin{array}{l}\text { О. Запорожець } \\
\text { [5] }\end{array}$ & $\begin{array}{l}\text { впроваджував гуманістичну психолого-педагогічну концепцію ампліфікації, } \\
\text { збагачення розвитку дитини, коли оптимальні умови для реалізації потенційних } \\
\text { можливостей дитини створюються не форсованим навчанням, а завдяки } \\
\text { збагаченню змісту навчання іграми, спілкуванням, образотворчою та } \\
\text { предметною діяльністю. } \\
\text { розглядала индивідуалізацію як граничний варіант диференціації, коли } \\
\text { навчальний процес будується з урахуванням особливостей не груп, а кожного } \\
\text { окремо взятого учня. }\end{array}$ \\
\hline
\end{tabular}

У сучасній педагогічній науковій літературі виділяють такі різновиди індивідуальної форми роботи: індивідуальна, індивідуалізована та індивідуалізовано-групова. Індивідуальну форму роботи застосовують на всіх етапах процесу навчання. Вона передбачає самостійне виконання учнями однакових завдань у єдиному темпі. Індивідуалізована форма характеризується такою організацією роботи, при якій кожен учень виконує специфічне завдання 3 урахуванням його навчальних можливостей. Індивідуалізовано-групова форма $€$ додатковою формою навчальної роботи, завдяки якій є можлиість не допустити відставання у навчанні слабких i створити кращі умови для розвитку обдарованих учнів. Серед видів індивідуальної роботи науковці виділяють: 
THEORETICAL FOUNDATIONS OF THE FUNCTIONING OF EDUCATION. WAYS TO IMPROVE THE EFFECTIVENESS OF EDUCATIONAL ACTIVITIES

діяльність окремого учня; виконання роботи учнем одночасно з іншими учнями класу, групи; різна тривалість виконання навчального завдання; виконання загальнокласної навчальної роботи; виконання окремого завдання. Індивідуальна форма роботи на уроці дає змогу враховувати темп навчання кожного учня, його підготовленість, створює можливості для диференціації завдань, контролю та оцінювання результатів, забезпечуючи відносну самостійність, але потребує значних затрат часу і зусиль учителя. В останні роки з явилися терміни «індивідуалізація навчання», «індивідуалізоване навчання», «індивідуальне навчання». Ми розглядаємо індивідуалізаџію навчання як принцуип здійснення індивідуального підходу до учнів у прочесі навчання; як форму організачії навчальної діяльності учнів на урочі; як освітню технологію, щзо трунтується на принц̧ипі індивідуалізащиї. «Індивідуалізоване навчання - вид навчання, що здійснюється на засадах індивідуалізації із застосовуванням відповідних технологій, метою якого $\epsilon$ розвиток індивіда згідно 3 його здібностями і в притаманному для нього темпі [7-11].

3 основних проблем, щзо виникають під час експериментальної роботи, ми відзначали такі: у багатьох учителів відсутні достатні знання про шляхи здійснення диференційованого та індивідуального підходу (30\%); виникають труднощі у виборі оптимальних способів і засобів диференціації (30\%); вчителі помиляються під час вибору варіанта навчальної діяльності учнів на різних етапах навчального процесу (15\%); не використовують варіативність застосування форм навчальної діяльності учнів (40\%); витрачають багато часу на власну підготовку до застосування складних форм організації навчальновиховного процесу та подальшу організацію навчальної діяльності учнів (80\%); відсутність у деяких підручниках чіткого поділу завдань різного рівня (45\%); швидкий темп навчання, перенасиченість зайвою інформацією (90\%). Дослідження розподілу часу на уроці, який реально займає у середньому кожна з основних форм навчальної діяльності (фронтальна, групова та індивідуальна) показало, що основне місце на уроці посідає фронтальна форма, яка охоплює біля 60\% уроку; груповій формі надається біля 25\%; індивідуальній - 15\% [11]. 
Отже, практика показала, що диференціація та індивідуалізація навчання забезпечують організацію особистісно орієнтованого підходу до учнів. Вивчення теоретичних основ індивідуалізації та диференціації навчання дає можливість вирішити основні дидактичні проблеми в будь-який період розвитку суспільства. 